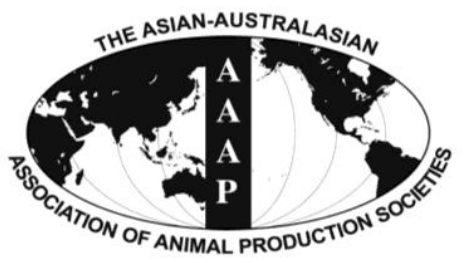

Asian-Aust. J. Anim. Sci.

Vol. 25, No. 9 : 1248 - 1254

September 2012

www.ajas.info

http://dx.doi.org/10.5713/ajas.2012.12081

\title{
The Effects of Additives in Napier Grass Silages on Chemical Composition, Feed Intake, Nutrient Digestibility and Rumen Fermentation
}

\author{
Smerjai Bureenok*, Chalermpon Yuangklang, Kraisit Vasupen, \\ J. Thomas Schonewille ${ }^{1}$ and Yasuhiro Kawamoto ${ }^{2}$ \\ Faculty of Natural Resources, Rajamangala University of Technology-Isan, \\ Sakon Nakhon Campus, Sakon Nakhon, Thailand
}

\begin{abstract}
The effect of silage additives on ensiling characteristics and nutritive value of Napier grass (Pennisetum purpureum) silages was studied. Napier grass silages were made with no additive, fermented juice of epiphytic lactic acid bacteria (FJLB), molasses or cassava meal. The ensiling characteristics were determined by ensiling Napier grass silages in airtight plastic pouches for $2,4,7,14$, 21 and $45 \mathrm{~d}$. The effect of Napier grass silages treated with these additives on voluntary feed intake, digestibility, rumen fermentation and microbial rumen fermentation was determined in 4 fistulated cows using $4 \times 4$ Latin square design. The $\mathrm{pH}$ value of the treated silages rapidly decreased, and reached to the lowest value within $7 \mathrm{~d}$ of the start of fermentation, as compared to the control. Lactic acid content of silages treated with FJLB was stable at $14 \mathrm{~d}$ of fermentation and constant until $45 \mathrm{~d}$ of ensiling. At $45 \mathrm{~d}$ of ensiling, neutral detergent fiber $(\mathrm{NDF})$ and acid detergent fiber $(\mathrm{ADF})$ of silage treated with cassava meal were significantly lower $(\mathrm{p}<0.05)$ than the others. In the feeding trial, the intake of silage increased $(\mathrm{p}<0.05)$ in the cow fed with the treated silage. Among the treatments, dry matter intake was the lowest in the silage treated with cassava meal. The organic matter, crude protein and NDF digestibility of the silage treated with molasses was higher than the silage without additive and the silage treated with FJLB. The rumen parameters: ruminal $\mathrm{pH}$, ammonia-nitrogen $\left(\mathrm{NH}_{3}-\mathrm{N}\right)$, volatile fatty acid (VFA), blood urea nitrogen (BUN) and bacterial populations were not significantly different among the treatments. In conclusion, these studies confirmed that the applying of molasses improved fermentative quality, feed intake and digestibility of Napier grass. (Key Words: Fermentation Quality, Lactic Acid Bacteria, Molasses, Cassava Meal)
\end{abstract}

\section{INTRODUCTION}

Napier grass (Pennisetum purpureum) is one of the most promising grasses available for ruminant production in tropical areas because of its high potential dry matter (DM) yield. However, both the DM content and the concentration of water soluble carbohydrates (WSC) are considered too low for successful ensiling. Furthermore, the number of epiphytic lactic acid bacteria (LAB) in Napier grass may be too low (Ohmomo et al., 2002; Yahaya et al., 2004) to ensure an uncomplicated process of fermentation. Indeed, it

\footnotetext{
* Corresponding Author: S. Bureenok. Tel: +66-4277-1460, Fax: +66-4277-1460, E-mail: asmerjai@hotmail.com

${ }^{1}$ Faculty of Veterinary Medicine, Department of Farm Animal Health, Division Nutrition, Utrecht University, The Netherlands.

${ }^{2}$ Faculty of Agriculture, University of the Ryukyus, Nishiharacho, Okinawa, Japan.

Submitted Feb. 10, 2012; Accepted Jun. 4, 2012; Revised Jun. 24, 2012
}

has been shown by Bureenok et al. (2006) that the addition of the fermented juice of epiphytic lactic acid bacteria (FJLB) to Napier grass improved the quality of the silage. In practice, molasses is widely used as an additive to enhance the process of ensiling (Yokota et al., 1991; Yunas et al., 2000; Van Niekerk et al., 2007) because of its high content of WSC. However, because of economical reasons, an alternative source of readily fermentable carbohydrates is desirable. In tropical regions, dry cassava chips are widely used as a local feed for ruminants and they contain a high amount of fermentable carbohydrates. Furthermore, cassava meal may stimulate the process of fermentation because of the absorption of excessive moisture by cassava meal (Panditharatne et al., 1986). The first objective of the current study was to evaluate the effects of additional FJLB, molasses or cassava meal on the process of fermentation of Napier grass. In general, silage making and the feeding of silage from Napier grass is not customary in tropical 
regions. Thus, there is a limited amount of information on the effect of method of ensiling on the feeding value of the whole ration. Therefore, the four silages from Napier grass as described earlier, were used to formulate four rations to evaluate the effects of method of ensiling on feed intake, selected indices of rumen fermentation and apparent digestibility of macro nutrients in dairy cows.

\section{MATERIALS AND METHODS}

\section{Preparation of FJLB}

FJLB was prepared from $200 \mathrm{~g}$ fresh Napier grass, which was immediately macerated in $1,000 \mathrm{ml}$ of sterilized distilled water with a home blender. The juice was filtered through a double layer of cheesecloth; the filtrate was transferred to a glass bottle and $2 \%$ glucose was added. Then, the bottle was capped and incubated anaerobically at $30^{\circ} \mathrm{C}$ for $2 \mathrm{~d}$.

\section{Preparation of the experimental silages}

Napier grass was harvested at the maturing stage after $90 \mathrm{~d}$ of re-growth and chopped with a forage cutter into pieces of 2 to $3 \mathrm{~cm}$. The chopped forages were treated with i) no additives; ii) FJLB; iii) molasses; or iv) cassava meal. The FJLB were applied at $1 \%$ of fresh weight which contained $5.58 \log _{10}$ colony-forming units (cfu)/g of total LAB. The molasses $(72.9 \%$ DM, $1 \%$ crude protein $(\mathrm{CP})$ and $24.7 \%$ WSC on a DM basis) and cassava meal (87.8\% DM, $1.5 \% \mathrm{CP}$ and $3.48 \%$ WSC on a DM basis) were applied at $5 \%$ of fresh weight. Distilled water (1\% of fresh weight) was added to the Napier grass without additive and the Napier grass with added molasses or cassava to adjust the moisture contents of the experimental forages. Thereafter, the experimental forages were packed tightly in plastic pouches. Air was withdrawn from the plastic pouches by means of a vacuum sealer. The pouches were stored at room temperature $\left(27\right.$ to $\left.30^{\circ} \mathrm{C}\right)$. The triplicate silages per treatment were opened on $2,4,7,14,21$ and $45 \mathrm{~d}$ of ensiling for chemical analysis. The experimental forages were also packed tightly in 200-litre plastic drums with clamp lid and stored until the start of the feeding trial.

\section{Animals and feeding}

All procedures were approved by the Ethical Principles for the Use of Animals for Scientific Purposes of the National Research Council of Thailand. Four ruminally fistulated Holstein Friesian $\times$ Red Shindi crossbred cows with a mean body weight of $403 \pm 88 \mathrm{~kg}$ were used. During the experiment they were individually housed in metabolic cages. The trial had a $4 \times 4$ Latin square design. The cows were randomly assigned to receive 1 of 4 ad libitum diets: i) no additive silage, ii) FJLB silage, iii) molasses silage, or iv) cassava silage. All cows were also fed $1.5 \%$ body weight (BW) of a concentrate containing $16 \% \mathrm{CP}$ (Table 1). The 28-d experimental period consisted of a $21 \mathrm{~d}$ of feed intake and $7 \mathrm{~d}$ of sampling. Feed was offered twice daily at 08:00 and 15:00 $\mathrm{h}$, and the refused portions were weighed daily before the morning feeding. Body weight (BW) was measured before the morning feeding at the beginning and end of each experimental period. The daily DM intake per unit of metabolic BW was calculated with the mean value of initial BW and final BW of each period.

\section{Collection of samples}

For the fermentative quality of silages, samples were taken at 2, 4, 7, 14, 21 and $45 \mathrm{~d}$ after closure of the plastic pouches. Subsamples (50 g fresh material) were macerated with $150 \mathrm{ml}$ of distilled water and stored in a refrigerator at $4^{\circ} \mathrm{C}$ for $12 \mathrm{~h}$ (Bureenok et al., 2006). Then, the extract was filtered (filter paper no.5; Whatman, England) and the $\mathrm{pH}$ of the extract was recorded ( $\mathrm{pH}$ meter, Lab 860, Schott). The filtrate was stored at $-20^{\circ} \mathrm{C}$ until the analysis of lactic acid, volatile fatty acids and $\mathrm{NH}_{3}-\mathrm{N}$.

At the end of each experimental period, rumen fluid was collected immediately at 0,2 , and $4 \mathrm{~h}$ after the morning feeding. The rumen fluid was immediately filtered through 2 layers of cheesecloth. The $\mathrm{pH}$ of the filtrates was measured with a glass electrode $\mathrm{pH}$ meter (Lab 860, Schott). The filtrates were divided into two portions. The first portion $(90 \mathrm{ml})$ was acidified with $10 \mathrm{ml}$ of $1 \mathrm{M} \mathrm{H}_{2} \mathrm{SO}_{4}$, centrifuged at $16,000 \times g$ for $15 \mathrm{~min}$, and the supernatant was stored at $-20^{\circ} \mathrm{C}$ until analysis of $\mathrm{NH}_{3}-\mathrm{N}$ and volatile fatty acids. The second portion was diluted for identification of bacterial groups (e.g., cellulolytic, proteolytic, amylolytic) with the roll-tube technique (Hungate, 1966).

A 20-ml blood sample from a jugular vein was collected into EDTA tubes at the same time as rumen fluid sampling. The plasma was separated by centrifugation at $2,500 \times g$ for

Table 1. Ingredients of the concentrate

\begin{tabular}{lc}
\hline Ingredient & $\mathrm{g} / \mathrm{kg}$ \\
\hline Cassava chips & 545 \\
Rice bran & 250 \\
Soybean meal & 41 \\
Whole cottonseed & 80 \\
Molasses & 44 \\
Urea & 18 \\
Salt & 9 \\
Oyster shells & 4 \\
Dicalcium phosphate & 4 \\
Sulfer & 1 \\
Premix &
\end{tabular}

${ }^{1}$ The premix consisted of (DM-basis) 44,000 IU of vitamin A/kg, 60,000 IU of $\mathrm{D}_{3} / \mathrm{kg}, 30,000 \mathrm{IU}$ of E/ $\mathrm{kg}, 11.6 \mathrm{~g} / \mathrm{kg}$ of Fe, $0.03 \mathrm{~g} / \mathrm{kg}$ of Co, 5.3 $\mathrm{g} / \mathrm{kg}$ of Mn, $5.6 \mathrm{~g} / \mathrm{kg}$ of Cu, $11.6 \mathrm{~g} / \mathrm{kg}$ of Zn, $0.07 \mathrm{~g} / \mathrm{kg}$ of I, $15.0 \mathrm{~g} / \mathrm{kg}$ of $\mathrm{P}, 10.0 \mathrm{~g} / \mathrm{kg}$ of $\mathrm{Mg}$ and $0.06 \mathrm{~g} / \mathrm{kg}$ of Se. 
15 min and stored at $-20^{\circ} \mathrm{C}$ until blood urea nitrogen (BUN) analysis was performed (Crocker, 1967).

During the last $7 \mathrm{~d}$ of each experimental period feces were collected quantitatively from each cow at the morning and afternoon, according to the total collection method. The daily feces production of each cow was mixed thoroughly, and $3 \%$ of the wet weight was stored at $-20^{\circ} \mathrm{C}$. At the end of each collection period, the stored feces fractions from each cow were combined, mixed thoroughly and sampled. Then, samples were dried, ground and stored in air-dry form in sealed jars at room temperature until analysis.

\section{Chemical analysis}

Lactic acid and volatile fatty acid in both rumen fluid and extract from Napier grass silages were determined by means of HPLC (Aminex ${ }^{\circledR}$ HPX-87H, $300 \mathrm{~mm} \times 7.8 \mathrm{~mm}$ i.d; column temperature, $40^{\circ} \mathrm{C}$; flow rate, $0.60 \mathrm{ml} / \mathrm{min}$, Shimzu Co., Ltd., Kyoto, Japan). The $\mathrm{NH}_{3}-\mathrm{N}$ contents of rumen fluid and silage extracts were determined using a steam distillation technique (Cai, 2004). The lactic acid bacteria (LAB) were plated out onto MRS agar and incubated at $35^{\circ} \mathrm{C}$ for $3 \mathrm{~d}$, after which viable colony-forming units (cfu) were determined (Kozaki et al., 1992).

The DM content of the silage, feed and feces were determined by oven drying at $60^{\circ} \mathrm{C}$ for $48 \mathrm{~h}$. The dried samples were milled to pass a $1.0 \mathrm{~mm}$ sieve. The concentration of WSC in forage was estimated as described by Dubois et al. (1956). The concentration of total nitrogen in forage and feces was determined by the Kjeldahl procedure and $\mathrm{CP}$ was calculated by multiplying $\mathrm{N}$ with 6.25 (AOAC, 1995). Neutral detergent fiber (NDF) and acid detergent fiber (ADF) concentrations in forage and feces were determined by methods as described by Van Soest et al. (1991). Blood urea nitrogen (BUN) was analyzed according to the method as described by Crocker (1967).

\section{Statistical analysis}

Statistical analyses were performed using the general linear models (GLM) procedure of SAS (SAS Institute Inc., Cary, NC, USA) for a completely randomized design for silage fermentation $(\mathrm{n}=3)$, while means differences between treatments determined using Duncan's new multiple range test (DMRT). Data from the feeding trial were analyzed using to the following statistical model (SAS, 1985):

$$
Y_{i j k}=\mu+A_{i}+P_{j}+D_{k}+e_{i j k}
$$

where $\mu$ is the overall mean, $A_{i}$ is the effect of animal ( $i$ $=1$ to 4$), P_{j}$ is the effect of period $(j=1$ to 4$)$, and $D_{k}$ is the effects of diet ( $k=1$ to 4$)$ and $e_{i j k}$ the residual variance, respectively. Rumen fermentation parameters and plasma metabolites were analyzed as repeated measures at 0,2, and $4 \mathrm{~h}$ after the morning feeding with the model (SAS, 1985):

$$
\mathrm{Y}_{\mathrm{ijkl}}=\mu+\mathrm{A}_{\mathrm{i}}+\mathrm{P}_{\mathrm{j}}+\mathrm{D}_{\mathrm{k}}+\delta_{\mathrm{ijk}}+\mathrm{T}_{\mathrm{l}}+\mathrm{DT}_{\mathrm{kl}}+\mathrm{e}_{\mathrm{ijk}}
$$

where $\mu, A_{i}, P_{j}, D_{k}$ are defined as previously described; $\mathrm{T}_{1}$ is the sampling time; $\mathrm{DTk}_{1}$ is the interaction between diet and time. Throughout, the level of statistical significance was set at $\mathrm{p}<0.05$.

\section{RESULTS}

\section{Fermentation quality}

Before the process of ensiling, the epiphytic LAB count in Napier grass was $10^{5} \mathrm{cfu} / \mathrm{g}$ fresh weight (Table 2) and this value rose to a value $>10^{8} \mathrm{cfu} / \mathrm{g}$ fresh weight after two

\begin{tabular}{|c|c|c|c|c|c|c|c|}
\hline & \multirow{2}{*}{ Before ensiling } & \multicolumn{4}{|c|}{ Experimental silages } & \multirow{2}{*}{ SEM } & \multirow{2}{*}{$\mathrm{p}$-value } \\
\hline & & No additive & FJLB & Molasses & Cassava & & \\
\hline $\mathrm{DM}(\mathrm{g} / \mathrm{kg})$ & 275 & $289^{\mathrm{a}}$ & $265^{\mathrm{b}}$ & $280^{\mathrm{ab}}$ & $293^{\mathrm{a}}$ & 5.8 & 0.0173 \\
\hline $\mathrm{NH}_{3}-\mathrm{N}(\mathrm{g} / \mathrm{kg}$ total $\mathrm{N})$ & NA & 73 & 63 & 68 & 67 & 4.5 & 0.5088 \\
\hline $\mathrm{pH}$ & 5.6 & $3.96^{\mathrm{a}}$ & $3.72^{\mathrm{b}}$ & $3.75^{\mathrm{b}}$ & $3.73^{\mathrm{b}}$ & 0.04 & 0.0002 \\
\hline $\mathrm{CP}$ & 41 & 43 & 49 & 45 & 45 & 3.6 & 0.4073 \\
\hline WSC & 90 & $12^{\mathrm{b}}$ & $15^{\mathrm{b}}$ & $24^{\mathrm{a}}$ & $13^{\mathrm{b}}$ & 2.8 & 0.0676 \\
\hline $\mathrm{NDF}$ & 748 & $712^{\mathrm{ab}}$ & $726^{\mathrm{a}}$ & $705^{\mathrm{b}}$ & $623^{c}$ & 9 & 0.0326 \\
\hline $\mathrm{ADF}$ & 401 & $470^{\mathrm{ab}}$ & $488^{\mathrm{a}}$ & $461^{\mathrm{b}}$ & $392^{\mathrm{c}}$ & 5.5 & $<0.0001$ \\
\hline Lactic acid & NA & $49^{c}$ & $79^{\mathrm{ab}}$ & $94^{\mathrm{a}}$ & $62^{\mathrm{bc}}$ & 5.6 & 0.0024 \\
\hline Acetic acid & NA & $10.9^{\mathrm{b}}$ & $9.2^{\mathrm{b}}$ & $20.8^{\mathrm{a}}$ & $7.2^{\mathrm{c}}$ & 2 & 0.0063 \\
\hline Propionic acid & NA & $1.7^{\mathrm{b}}$ & $3.7^{\mathrm{a}}$ & $\mathrm{ND}^{\mathrm{c}}$ & $\mathrm{ND}^{\mathrm{c}}$ & 0.43 & 0.0010 \\
\hline Butyric acid & NA & $16.1^{\mathrm{a}}$ & $5.9^{\mathrm{b}}$ & $7.7^{\mathrm{b}}$ & $2.7^{\mathrm{b}}$ & 3.22 & 0.1590 \\
\hline
\end{tabular}

Table 2. Chemical composition of Napier grass, before and after, ensiling for a period of 45 days

NA = Not analyzed, and ND = Non detectable; zero value was used in statistical analysis.

FJLB = Fermented juice of epiphytic lactic acid bacteria; $\mathrm{DM}=$ Dry matter; $\mathrm{NH}_{3}-\mathrm{N}=$ Ammonia-nitrogen; $\mathrm{N}=\mathrm{Nitrogen}$; $\mathrm{CP}=\mathrm{Crude}$ protein; WSC = Water soluble carbohydrates; NDF = Neutral detergent fiber; $\mathrm{ADF}=$ Acid detergent fiber; $\mathrm{SEM}=$ Standard error of means

Values in the same row followed by different letters are significantly different $(\mathrm{p}<0.05)$. 

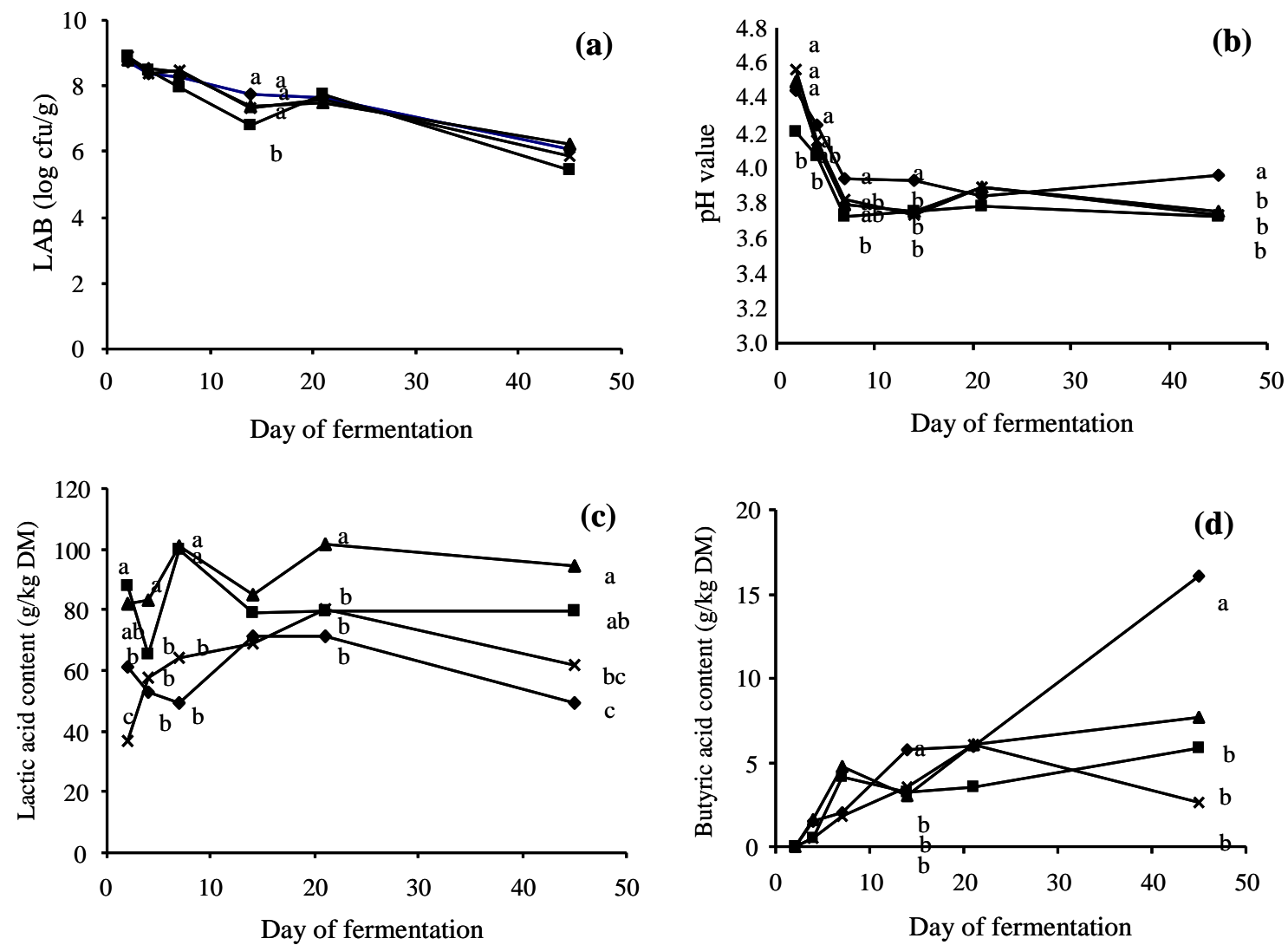

Figure 1. Changes in LAB counts (panel a), $\mathrm{pH}$ value (panel b), lactic acid (panel c) and butyric acid (panel d) during the ensiling period. Values are means of three silage samples. Different letters indicate a significant difference between treatments $(\mathrm{p}<0.05)$. Symbols: $\bullet$, no additive; $\mathbf{\square}$, FJLB; $\boldsymbol{\Lambda}$, molasses; $\times$, cassava meal.

days of ensiling (Figure 1a). In the course time, LAB counts declined to approximately $10^{6} \mathrm{cfu} / \mathrm{g}$ fresh weight and were not different among silages. All three additives rapidly decreased silage $\mathrm{pH}$ which reached the lowest value within $7 \mathrm{~d}$ of the start of fermentation, as compared to the control (Figure 1b). Lactic acid levels varied with the time of ensiling and among the silage treatments (Figure 1c). Despite the high levels of lactic acid in the silages treated with FJLB and molasses, $\mathrm{pH}$ values were not significantly different between the silages treated with additives. Butyric acid concentrations rose during the first $20 \mathrm{~d}$ of fermentation, irrespective of treatment. Thereafter, butyric acid concentration remained constant in the silages with additives while it further increased in the silage without additive (Figure 1d). After $45 \mathrm{~d}$ of fermentation, the highest acetic acid concentrations were observed in the silage with molasses, while the lowest value was observed in the silage added with cassava meal (Table 1). Propionic acid could not be detected in the silages treated with molasses or cassava while the highest propionic concentration was observed in the FJLB treated silage. The process of fermentation clearly decreased the WSC content of Napier grass but the decrease in WSC content was the lowest in the silage treated with molasses. The CP content of Napier grass silages were neither affected by the ensiling process nor by any additive used in the current experiment. This observation is in line with the fact that $\mathrm{NH}_{3}-\mathrm{N}$ also was not significantly influenced by any treatment. The use of cassava meal significantly lowered the NDF and ADF contents of the silages.

\section{Feed intake and digestibility}

The intake of silage was clearly affected by treatment (Table 3). DM intake of silage was significantly higher when molasses was used as a silage additive while the use of cassava meal resulted in the lowest DM intake of silage. Because all cows consumed the same amount of concentrate, total DM intake showed the same pattern as DM intake from silage. The use of molasses as a silage additive was associated with a significantly higher DM digestibility compared to the silage without additive. The digestibility of organic matter (OM), $\mathrm{CP}$ and NDF was similar for the silage without additive and the silages treated with FJLB or cassava meal. The intake of silage treated with molasses resulted in significantly higher digestibility of $\mathrm{OM}, \mathrm{CP}$ and NDF compared to silage without additive and the silage treated with FJLB. The digestibility of ADF was not affected by treatment. 
Table 3. Voluntary feed intake (VFI) and nutrient digestibility in cows fed the experimental silages

\begin{tabular}{|c|c|c|c|c|c|c|}
\hline & No additive & FJLB & Molasses & Cassava & SEM & p-value \\
\hline \multicolumn{7}{|l|}{ Total VFI } \\
\hline$\% \mathrm{BW}$ & $2.14^{\mathrm{b}}$ & $2.19^{b}$ & $2.41^{\mathrm{a}}$ & $2.12^{\mathrm{b}}$ & 0.02 & 0.0310 \\
\hline $\mathrm{g} / \mathrm{kg} \mathrm{BW} \mathrm{W}^{0.75}$ & $94.8^{\mathrm{c}}$ & $99.2^{\mathrm{b}}$ & $108^{a}$ & $95.1^{\mathrm{c}}$ & 0.01 & $<0.0001$ \\
\hline \multicolumn{7}{|l|}{ Silage intake } \\
\hline$\% \mathrm{BW}$ & $0.79^{\mathrm{b}}$ & $0.84^{\mathrm{b}}$ & $1.06^{\mathrm{a}}$ & $0.77^{\mathrm{b}}$ & 0.02 & 0.0269 \\
\hline $\mathrm{g} / \mathrm{kg} \mathrm{BW} \mathrm{W}^{0.75}$ & $35.1^{\mathrm{b}}$ & $38.57^{\mathrm{b}}$ & $47.62^{\mathrm{a}}$ & $34.73^{b}$ & 1.24 & 0.0030 \\
\hline \multicolumn{7}{|l|}{ Digestibility (\%) } \\
\hline $\mathrm{DM}$ & $75.64^{\mathrm{b}}$ & $75.99^{a b}$ & $81.54^{\mathrm{a}}$ & $76.18^{\mathrm{ab}}$ & 1.43 & 0.0943 \\
\hline $\mathrm{OM}$ & $77.43^{\mathrm{b}}$ & $77.82^{\mathrm{b}}$ & $83.22^{\mathrm{a}}$ & $78.06^{\mathrm{ab}}$ & 1.36 & 0.0878 \\
\hline $\mathrm{CP}$ & $76.95^{\mathrm{b}}$ & $75.27^{\mathrm{b}}$ & $81.09^{a}$ & $77.5^{\mathrm{ab}}$ & 0.98 & 0.0454 \\
\hline NDF & $66.6^{\mathrm{b}}$ & $67.26^{\mathrm{b}}$ & $76.75^{a}$ & $68.57^{\mathrm{b}}$ & 1.76 & 0.0314 \\
\hline $\mathrm{ADF}$ & 66.76 & 67.63 & 76.33 & 65.22 & 2.91 & 0.1382 \\
\hline
\end{tabular}

FJLB = Fermented juice of epiphytic lactic acid bacteria; $\mathrm{BW}=$ Body weight; $\mathrm{DM}=$ Dry matter, OM = Organic matter, $\mathrm{CP}=\mathrm{Crude}$ protein; NDF = Neutral detergent fiber; $\mathrm{ADF}=$ Acid detergent fiber; $\mathrm{SEM}=$ Standard error of means.

Values in the same row followed by different letters are significantly different $(\mathrm{p}<0.05)$.

\section{Rumen fermentation and microorganism population}

It appeared that the molar proportions $(\mathrm{mol} / 100 \mathrm{~mol})$ of acetic-, propionic- and butyric acid were not significantly affected by the experimental silages used after feeding (Table 4). The mean ruminal $\mathrm{pH}$ value (6.5 to 6.9) was similar in all four treatments. The rumen $\mathrm{NH}_{3}-\mathrm{N}$ content was 17.1 to $20.8 \mathrm{mg} / \mathrm{dl}$ and did not differ significantly among treatments. The viable cellulolytic, amylolytic, proteolytic bacteria and protozoa populations (log $\mathrm{cfu} / \mathrm{ml})$ were not significantly different between treatments. The BUN concentrations ranged from 13.3 to $17.2 \mathrm{mg} / \mathrm{dl}$ between experimental treatments but these differences were not statistically significant.

\section{DISCUSSION}

\section{Fermentation quality}

In practice, parameters such as silage $\mathrm{pH}$, short chain fatty acids and ammonia content are valuable indicators of silage quality. It is generally accepted that in silage $\mathrm{pH}$ values should be $<4.5$, lactate $>30 \mathrm{~g} / \mathrm{kg}$ DM (McDonald et al., 1991) and $\mathrm{NH}_{3}-\mathrm{N}$ content should not exceed $100 \mathrm{~g} / \mathrm{kg}$ total nitrogen (Umana et al., 1991). Clearly, all the experimental silages met these criteria. Interestingly, LAB count was similar for the silage without additive and that with additional LAB while the lactic acid content was significantly higher in the silage with the FJLB. Thus, it seems that the content of intrinsic WSC in Napier grass did not limit lactate production. Apparently, the amount of epiphytic LAB in Napier grass was high enough to ensure a proper process of ensiling. On the other hand, butyric acid content of the silage without additive was high; i.e. $21 \%$ of total short chain fatty acids. Such a value is too high; according to McDonald (1991) silages containing more than $10 \%$ butyric acid (\% of total short chain fatty acids) are poorly preserved. The high butyric acid content of the silage without additive may be explained by the relative low osmotic pressure of the fresh Napier grass due to its high

Table 4. Effects of silage additives on rumen fermentation characteristics and microbial counts in cows fed the experimental silages

\begin{tabular}{|c|c|c|c|c|c|c|}
\hline & \multicolumn{4}{|c|}{ Experimental silages } & \multirow{2}{*}{ SEM } & \multirow{2}{*}{ p-value } \\
\hline & No additive & FJLB & Molasses & Cassava & & \\
\hline $\mathrm{pH}$ & 6.8 & 6.9 & 6.5 & 6.8 & 0.21 & 0.6820 \\
\hline Acetic acid, $\mathrm{C}_{2}(\mathrm{~mol} / 100 \mathrm{~mol})$ & 72.6 & 72.2 & 70.6 & 67.3 & 4.08 & 0.3912 \\
\hline Propionic acid, $\mathrm{C}_{3}(\mathrm{~mol} / 100 \mathrm{~mol})$ & 18.2 & 17.9 & 18.5 & 19.5 & 3.14 & 0.7506 \\
\hline Butyric acid, $\mathrm{C}_{4}(\mathrm{~mol} / 100 \mathrm{~mol})$ & 9.2 & 9.9 & 10.7 & 13.2 & 1.6 & 0.3241 \\
\hline $\mathrm{NH}_{3}-\mathrm{N}(\mathrm{mg} / \mathrm{dl})$ & 17.1 & 17.6 & 20.1 & 20.8 & 1.18 & 0.1635 \\
\hline BUN (mg/dl) & 13.3 & 17.2 & 13.6 & 15.4 & 2.66 & 0.7258 \\
\hline \multicolumn{7}{|l|}{ Viable bacteria (log cfu/ml) } \\
\hline Amylolytic bacteria & 5.8 & 5.7 & 5.5 & 5.4 & 0.05 & 0.6422 \\
\hline Proteolytic bacteria & 5.8 & 5.9 & 6.1 & 5.7 & 0.18 & 0.4397 \\
\hline Cellulolytic bacteria & 7.1 & 7.2 & 7.3 & 7.2 & 0.17 & 0.7874 \\
\hline
\end{tabular}

FJLB = Fermented juice of epiphytic lactic acid bacteria; $\mathrm{NH}_{3}-\mathrm{N}$ : Ammonia-nitrogen, $\mathrm{BUN}=$ Blood urea nitrogen; SEM = Standard error of means . 
moisture content (Muck, 1988). The practical relevance of high levels of butyric acid lies in the implication that feed intake might be reduced due to a reduced palatability (Rook and Gill, 1990). Both the absolute content and relative content ( $\%$ of total short chain fatty acids) of acetic acid were highest in the silage treated with molasses; values being $20.8 \mathrm{~g} / \mathrm{kg} \mathrm{DM}$ and $17 \%$ respectively. The underlying reason is not clear but it might be speculated that the use of molasses stimulated the growth of hetero-fermentative instead of homo-fermentative LAB due to the specific source of WSC in molasses; i.e. sucrose (Steg et al., 1985). It has been mentioned previously that the lactic acid content was also very high in the silage with additional molasses. The concomitant production of lactic acid and acetic acid is considered positive because acetic acid increases the aerobic stability due to the inhibition of spoilage organisms (Danner et al., 2003). It has been indicated by Lima et al. (2010) that a good quality of silage is associated at least $70 \%$ but no more than $90 \%$ lactic acid and no more than $20 \%$ acetic acid (\% of total short chain fatty acids). Thus, taken aforementioned considerations into account, molasses can be considered as the most promising additive to ensile Napier grass.

Similar to the addition of molasses, the addition of cassava meal to Napier grass resulted in increased lactic acid contents compared with the untreated silage but the difference just failed to reach statistical significance when cassava meal instead of molasses was used. Despite the fact that both molasses and cassava are rich in carbohydrates, cassava meal versus molasses contains high amounts of starch and low amounts of WSC. Apparently, lactate production is more efficient when WSC instead of starch is fermented (Sibanda et al., 1997).

The NDF content of Napier grass was clearly affected by the process of fermentation. The reduction of NDF content observed in the all the experimental silages may be explained by the hydrolysis of NDF-bound N (Jaakkola et al., 2006; Huisden et al., 2009) during fermentation. NDF was lower in molasses and cassava meal silages compared with the untreated and FJLB silages. This can be explained in that the addition of $5 \%(\mathrm{w} / \mathrm{w})$ of molasses and cassava meal (non-fiber sources) may dilute the proportion of these fibers. ADF content in the silage was increased when compared with the material crops that may be caused by the losses of other components during the fermentation (Jaakkola et al., 2006).

\section{Feed intake and digestibility}

Interestingly, addition of molasses to Napier grass versus no additive resulted in a 1.4 times higher intake of silage. The increase in silage intake may be explained, at least partially, by the higher residual WSC content in the silage treated with molasses (Murphy, 1999). Alternatively, it has been discussed that the aerobic stability of the silage with molasses was increased thereby potentially preventing the growth of spoilage organisms (Danner et al., 2003). However, the plastic drums used in this study were finished in 2 to $3 \mathrm{~d}$ and special care was taken when the drums were closed after each feeding. Thus, aerobic deterioration may not have been too important during this feeding trial. Nevertheless, it may be speculated that silages prepared with molasses are advantageous to stimulate dry matter intake.

The increase in DM and OM digestibility for silages ensiled with molasses are in line with the observed lower NDF content of this silage. In contrast, addition of cassava meal to Napier grass did not improve nutrient digestibility. Indeed, cassava meal is rich in energy and is highly rumen degradable (Wanapat, 2009). It may be speculated that the addition at a level of 5\% was too low to affect digestibility. Indeed, it was shown by Yang et al. (2004) that addition of $10 \%$ corn meal improved NDF digestibility of silage from Napier grass.

\section{Rumen fermentation and microorganism population}

In this study, selected indices of rumen fermentation were not affected by any treatment. This lack of effect of experimental treatments on rumen fermentation may be explained by the relative low level of DM intake. This explanation is corroborated by the observations of both Schonewille et al. (2000) and Pilachai et al. (2011), whom also could not demonstrate a clear effect of readily fermentable carbohydrates on rumen fermentation when cows were fed less than $10.5 \mathrm{~kg} \mathrm{DM} / \mathrm{d}$. Thus, it may be that the level of DM intake in the present study was too low to effectively influence the process of rumen fermentation.

The outcome of this study suggests that molasses is the most suitable alternative to enhance the ensiling process in Napier grass.

\section{ACKNOWLEDGEMENTS}

This work was supported by the National Research Council of Thailand (NRCT).

\section{REFERENCES}

AOAC, 1995. Official methods of analysis, 16th ed. Association of Official Analytical Chemists, Arlington. VA, USA.

Bureenok, S., T. Namihira, S. Mizumachi, Y. Kawamoto and T. Nakada. 2006. The effect of epiphytic lactic acid bacteria with or without different byproduct from defatted rice bran and green tea waste on napiergrass (Pennisetum purpureum Schumach) silage. J. Sci. Food Agric. 86:1073-1077.

Cai, Y. 2004. Methods for feed evaluation of forages: Silage Analyses. In Japan Society of Grassland Science (ed.): Field and Laboratory Methods for Grassland Science. Japan 
Livestock Technology Association, Tokyo, pp. 279-283.

Crocker, C. L. 1967. Rapid determination of urea-nitrogen in serum or plasma without deproteinazation. Am. J. Med. Technol. 33:361-365.

Danner, H., M. Holzer, E. Mayrhuber and R. Braun. 2003. Acetic acid increases stability of silage under aerobic conditions. Appl. Environ. Microbiol. 69:562-567.

Dubois, M., K. A. Gilles, J. K. Hamilton, P. A. Rebers and F. Smith. 1956. Calorimetric method for determination of sugars and related substances. Anal. Chem. 28:350-356.

Huisden, C. M., A. T. Adesogan, S. C. Kim and T. Ososanya. 2009. Effect of applying molasses or inoculants containing homofermentative or heterofermentative bacteria at two rates on the fermentation and aerobic stability of corn silage. J. Dairy Sci. 92:690-697.

Hungate, R. E. 1966. The rumen and its microbes. Academic Press, New York, USA.

Jaakkola, S., V. Kaunisto and P. Huhtanen. 2006. Volatile fatty acid proportions and microbial protein synthesis in the rumen of cattle receiving grass silage ensiled with different rates of formic acid. Grass and Forage Sci. 61:282-292.

Kozaki, M., T. Uchimura and S. Okada. 1992. Experimental manual of lactic acid bacteria. Asakurashoten, Tokyo.

Lima, R., R. F. Diaz, A. Castro, S. Hoedtke and V. Fievez. 2010. Multifactorial models to assess responses to sorghum proportion, molasses and bacterial inoculant on in vitro quality of sorghum-soybean silages. Anim. Feed Sci. Technol. 164: 161-173.

McDonald, P., A. R. Henderson and S. J. E. Heron. 1991. The Biochemistry of silage (2nd Ed.) Chalcombe Publications, Marlow Bucks, UK.

Muck, R. E. 1988. Factors influencing silage quality and their implications for management. J. Dairy Sci. 71:2992-3002.

Murphy, J. J. 1999. The effects of increasing the proportion molasses in the diet of milking dairy cows on milk production and composition. Anim. Feed Sci. Technol. 78:189-198.

Ohmomo, S., O. Tanaka, H. K. Kitamoto and Y. Cai. 2002. Silage and microbial performance, old story but new problems. Jpn. Agr. Res. Q. 36:59-71.

Panditharatne, S., V. G. Allen, J. P. Fontenol and M. C. N. Jayasuria. 1986. Ensiling characteristics of tropical grasses as influenced by stage of growth, additives and chopping length. J. Anim. Sci. 63:197-207.

Pilachai, R., J. T. Schonewille, C. Thamrongyoswittayakul, S Aiumlamai, C. Wachirapakorn, H. Everts and W. H. Hendriks. 2011. The effects of high levels of rumen degradable protein on rumen $\mathrm{pH}$ and histamine concentrations in dairy cows. J. Anim. Physiol. Anim. Nutr. 96:206-213. doi: 10.1111/j.14390396.2011.01139.x
Rook, A. J. and M. Gill. 1990. Prediction of the voluntary intake of grass silages by beef cattle. 1. Linear regression analysis. Anim. Prod. 50:425-438.

SAS Institute, 1985: User's guide: Statistics. SAS Institute Inc., Cary, NC, USA.

Schonewille, J. T., A. T. Van't Klooster, J. W. Cone, H. J. Kalsbeek-Van der Valk, H. Wouterse and A. C. Beynen. 2000. Neither native nor popped cornmeal in the ration of dry cows affects magnesium absorption. Livest. Prod. Sci. 63:17-26.

Sibanda, S. R., M. Jingura and J. H. Topps. 1997. The effect of level of inclusion of the legume Desmodium uncinatum and the use of molasses or ground maize as additives on the chemical composition of grass- and maize-legume silages. Anim. Feed Sci. Technol. 68:295-305.

Steg, A. and J. M. Van Der Meer. 1985. Differences in chemical composition and digestibility of beet and cane molasses. Anim. Feed Sci. Technol. 13:83-91.

Umana, R., C. R. Staples, C. B. Bates, C. J. Wilcox and W. C. Mahanna. 1991. Effects of a microbial inoculant and (or) sugarcane molasses on the fermentation, aerobic stability, and digestibility of bermudagrass ensiled at two moisture contents. J. Anim. Sci. 69:4588-4601.

Van Neikerk, W. A., A. Hassen, F. M. Bechaz and R. J. Coertze. 2007. Fermentative attributes of wilted vs. unwilted Digitaria eriantha silage treated with or without molasses at ensiling. S. Afr. J. Anim. Sci. 37:261-268.

Van Soest, P. J., J. B. Robertson and B. A. Lewis. 1991. Methods for dietary fiber, neutral detergent fiber, and nonstarch polysaccharides in relation to animal nutrition. J. Dairy Sci. 74:3583-3597.

Wanapat, M. 2009. Potential uses of local feed resources for ruminant. Trop. Anim. Health Prod. 41:1035-1049.

Yahaya, M. S., M. Goto, W. Yimiti, B. Smerjai and Y. Kawamoto. 2004. Additives effects of fermented juice of epiphytic lactic acid bacteria and acetic acid on silo fermentation and ruminal degradability of tropical elephant grass. J. Anim. Vet. Adv. 3: 115-121.

Yang, C. M., J. S. Haung, C. T. Chang, Y. H. Cheng and C. Y. Chang. 2004. Fermentation acids, aerobic fungal growth and intake of napier grass ensiled with nonfiber carbohydrates. J. Dairy Sci. 87:630-636.

Yokota, H., T. Okajima and M. Ohshima. 1991. Effect of environmental temperature and addition of molasses on the quality of Napier grass (Pennisetum purpureum) silage. AsianAust. J. Anim. Sci. 4:377-382.

Yunus, M., N. Ohba, M. Shimojo, M. Furuse and Y. Masuda. 2000. Effects of adding urea and molasses on Napiergrass silage quality. Asian-Aust. J. Anim. Sci. 13:1542-1547. 